\title{
Experimental pilot study after surgery on a food supplement for athletes to protect articular knee cartilage. A functional and biochemical study
}

\author{
Jesús Alfaro-Adrián', Miriam Araña Ciordia², Miguel Barajas Vélez² \\ 'Unidad de Artroscopia y Traumatología Deportiva. Clínica San Miguel. Pamplona. Navarra. ${ }^{2}$ Departamento de Bioquímica. Universidad Pública de Navarra (UPNA). Campus de \\ Arrosadia. Pamplona. Navarra.
}

doi: 10.18176/archmeddeporte.00039

Received: $31 / 03 / 2020$ Accepted: 03/02/2021

Key words: Carticure Plus ${ }^{\circledast}$. Arthroscopy. Knee.

\section{Summary}

This double-blind experimental study evaluates the efficacy of chondroprotective supplementation (Carticure Plus ${ }^{\circledast}$, 5000 mg Collagen - Bioactive Peptides, 1500 mg Glucosamine Hydrochloride, 1200 mg Chondroitin Sulfate, 1.1 mg Copper, 80 mg Vitamin C, 2 mg Manganese) in patients with meniscal and ligament pathology who have required arthroscopic surgery. 12 patients with ligamentous injury and 12 patients with meniscopathy were selected, who underwent the measurement of different inflammatory markers using ELISA, collagen 2A and hyaluronic acid, in addition to evaluating pain as well as functionality and quality of life through VAS (Visual Analogue Scale), WOMAC (Western Ontario McMaster Universities Osteoarthritis Index) and KOOS (Knee Injury and Osteoarthritis Outcome Score). Statistically significant differences of clinical improvement were observed in favor of Carticure Plus ${ }^{\oplus}$, with an improvement in the functional capacity of the WOMAC scale, 76\% Carticure Plus $^{\circledast}$ vs $53 \%$ placebo, for all patients and with a clear improvement in the first month in meniscal injury, in improvement of the activities of daily life (KOOS), Carticure Plus ${ }^{\circledast} 31 \%$ vs placebo -1\%, sports activity, (Carticure Plus ${ }^{\circledR} 41 \%$ vs placebo 13,2\%) and sports and recreational activities (KOOS) (Carticure Plus ${ }^{\circledR} 128 \%$ vs Placebo 10,4\%).

On the other hand, in ligamentous injury an improvement in quality of life (KOOS) Carticure Plus ${ }^{\oplus} 75 \%$ vs Placebo $-8,8 \%$ and pain (KOOS) Carticure Plus ${ }^{\oplus} 49,6 \%$ vs Placebo 0,3\% was observed in the first month compared to the baseline. In the patient group, pain (KOOS) Carticure Plus ${ }^{\circledast} 31,4 \%$ vs Placebo 1,3\% and activities of daily living (KOOS) Carticure Plus ${ }^{\circledR} 43,9 \%$ vs Placebo $27,1 \%$ in the third month from baseline, are associated with an improvement due to Carticure Plus ${ }^{\circledast}$ when compared to the placebo group. Despite the small sample size, it is remarkable the fact that statistically significant differences have been found, the efficacy of Carticure Plus ${ }^{\circledast}$ could be assumed.

\section{Estudio experimental piloto tras cirugía del uso de un complejo alimenticio en deportistas para la protección del cartílago articular de rodilla. Un estudio funcional y bioquímico}

Palabras clave: Ligamento cruzado. Menisco. Carticure Plus ${ }^{\oplus}$. Artroscopia. Rodilla.

\begin{abstract}
Resumen
En este estudio experimental doble ciego se evalúa la eficacia de la suplementación condroprotectora (Carticure Plus ${ }^{\circledR}, 5000$ mg Colágeno (Péptidos Bioactivos) altamente asimilable, 1500 mg Glucosamina clorhidrato, 1200 mg Condroitín sulfato, 1,1 mg Cobre, 80 mg Vitamina C, 2 mg Manganeso) en pacientes con patología ligamentosa y meniscal que han requerido cirugía artroscópica. Se seleccionaron 12 pacientes con lesión ligamentosa y 12 pacientes con meniscopatía a los que se les procedió a la medición de distintos marcadores inflamatorios mediante ELISA, colágeno 2A y ácido hialurónico, además de a la evaluación del dolor así como la funcionalidad y calidad de vida a través de EVA (Escala Visual Analógica), WOMAC (Western Ontario McMaster Universities Osteoarthritis Index) y KOOS (Knee Injury and Osteoarthritis Outcome Score). Se observaron diferencias estadísticamente significativas de mejoría clínica a favor de Carticure Plus ${ }^{\oplus}$, con una mejora de la capacidad funcional de la escala WOMAC del $76 \%$ frente a un 53\% del placebo para el conjunto de pacientes y con una clara mejoría en el primer mes en lesión meniscal, en mejora de las actividades de la vida diaria (KOOS), Carticure Plus ${ }^{\circledR} 31 \%$ frente a placebo - $1 \%$, actividad deportiva (Carticure Plus ${ }^{\oplus} 41 \%$ vs Placebo 13,2\%), actividades deportivas y recreativas (Carticure Plus ${ }^{\oplus} 128 \%$ vs Placebo 10,4\%). Por otro lado, en lesión ligamentosa se observa una mejoría en calidad de vida (KOOS) Carticure Plus ${ }^{\circledR} 75 \%$ vs Placebo $-8,8 \%$ y dolor (KOOS) Carticure Plus ${ }^{\oplus} 49,6 \%$ vs Placebo 0,3\% en el primer mes respecto al basal. En el conjunto de pacientes, el dolor (KOOS) Carticure Plus ${ }^{\oplus} 31,4 \%$ vs Placebo 1,3\% y actividades de la vida diaria (KOOS) Carticure Plus ${ }^{\circledast}$ 43,9\% vs Placebo $27,1 \%$ en el tercer mes respecto al basal se asocian a una mejora a Carticure Plus ${ }^{\oplus}$ en comparación al placebo. A pesar del pequeño tamaño muestral, es destacable el hecho de haber encontrado diferencias estadísticamente significativas que podría presuponer la eficacia de Carticure Plus ${ }^{\circledast}$.
\end{abstract}




\section{Introduction}

The Anterior Cruciate Ligament (ACL) injury is one of the most frequent ligament injuries among athletes, with an estimated incidence of 35/100,000 per year ${ }^{1}$. The standard treatment for these injuries is surgery as a general rule. The operation aims to stabilise the joint in an attempt to slow down the development of degenerative changes in it, in other words articular Osteoarthritis (OA). Despite this, the incidence of developing osteoarthritis after $\mathrm{ACL}$ reconstructions is high and furthermore, this risk increases if there is a meniscus injury involved ${ }^{2,3}$.

Although incidence of meniscus repairs has been soaring over the last few years ${ }^{4}$, for most patients who need operations on symptomatic meniscal injuries from the age of 30 onwards, a selective subtotal meniscectomy is usually still performed plus regularisation of the meniscal injury.

In other words, at least one third of these patients develop progressive $O A$ in their knee in the first decade after the injury and the majority of them in the second decade ${ }^{5}$.

Despite this, there is no effective treatment to halt this process. In one way or another, we might say that meniscal and ligament injuries of the knee lead the way to osteoarthritis ${ }^{6,7}$. In addition to classic functional scales, it might be interesting to evaluate biochemical markers that can indicate abnormal articular situations after surgery on this type of injury to understand and attempt to slow down this development ${ }^{8}$.

Given that there is no scientific evidence of the impact of oral condroprotector supplements among patients with ligament and meniscal pathologies who require arthroscopic surgery, it is proposed to carry out an experimental, double-blind pilot study to evaluate the effectiveness of Carticure Plus ${ }^{\circledR}$.

\section{Material and method}

Experimental, double-blind, pilot study, with two random treatment assignment branches (Carticure Plus ${ }^{\oplus}$ vs. placebo), analysing the effects on pain and different systemic markers among 24 amateur athletes aged between 30 and 50 years old. The indication for arthroscopy among patients with meniscal pathologies included in the study will be made by following usual clinical practice and good clinical practice guides. This excluded relevant interactions or known contraindications (hypersensitivity or allergies) with the excipients or the components of Carticure Plus ${ }^{\circledast}$ / placebo, patients who had received knee surgery on a previous occasion, diabetes mellitus, pregnancy or breast-feeding.

These patients were selected by ranking them into 12 patients with meniscopathy and 12 with an ACL ligament injury who received arthroscopy surgery and then took 1 sachet a day of Carticure Plus ${ }^{\circledR}$ (bioactive peptide made of 5,000 mg collagen, 1,200 mg chondroitin sulphate, 1,500 mg glucosamine hydrochloride, $80 \mathrm{mg}$ ascorbic acid (Vitamin C), 2 mg manganese and $1.1 \mathrm{mg}$ copper) compared to a placebo for three months.
The study variables were measurement of various blood markers using the ELISA test: pro-inflammatory/catabolism (PCR, IL-6, IL-1B, TNF-alfa), anabolism (TGF-beta and FGF-21), collagen 2A and hyaluronic acid. Various scales and questionnaires were also used to evaluate pain, functionality and quality of life. Pain was assessed using the Visual Analogue Scale (VAS) which represents intensity along a $10 \mathrm{~cm}$ line numbered from 0 to 10, where 0 represents "no pain" and the other end is "the worst pain imaginable" Osteoarthritis Index (WOMAC) questionnaire: this is one of the best questionnaires from the point of view of its psychometric properties. This questionnaire contains three subscales that measure pain, rigidity and functional capacity ${ }^{10}$; KOOS Scale (Knee Injury and Osteoarthritis Outcome Score): questionnaire validated in the Spanish population. It evaluates several aspects: symptoms, rigidity, pain, daily activities, sports and recreational activities and quality of life ${ }^{11}$.

Given the sample size, a non-parametric, $U$ by Mann-Whitney, test compares independent data on the mean difference in the quantitative variables from the first, second and third month compared to the baseline value, for each pathological group and in total. Consequently, this compares improvements in pain (EVA), WOMAC questionnaire and KOOS questionnaire between the baseline visit and the rest of the monitoring (Table 1) among the patients who took Carticure Plus ${ }^{\circledR}$ and the placebo, both in the meniscus and ligament pathologies as a whole and separately.

The study took place at the Arthroscopy and Sports Orthopaedic Unit, Clínica San Miguel in Pamplona (Navarre) and it was approved by the Ethics Committee. All the patients gave their informed consent voluntarily after receiving information on the study.

The data obtained from the pilot study were used to evaluate whether to carry out a study with greater statistical power and select the main variable for the study.

The promoter asked the ARAFARMA GROUP S.A. laboratory to donate the food and fund the monitoring in the study. There are no conflicts of interest for the authors.

Table 1. Time frame for collecting variables.

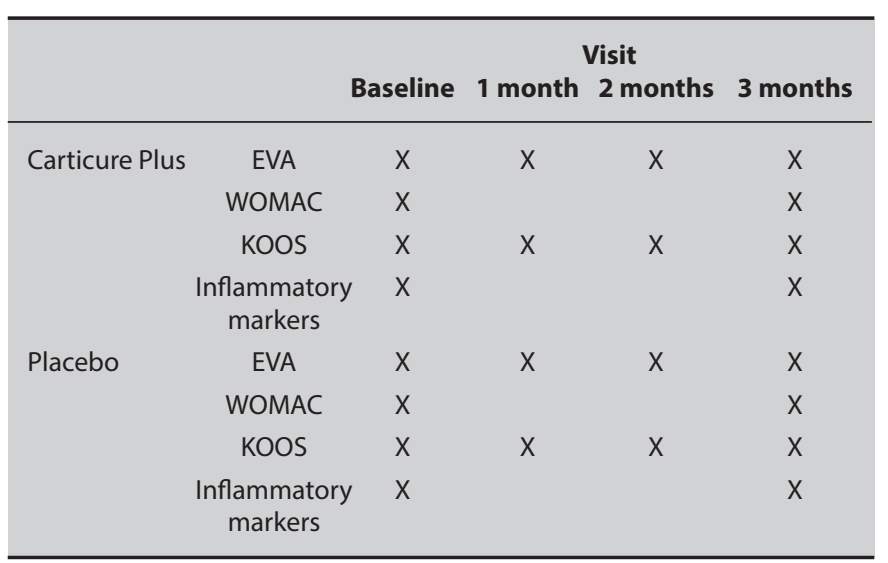




\section{Results}

Patients with a meniscus injury not associated with a ligament injury or a deficit of rough tissue were $83.3 \%$ men who played various sports (running, football, crossfit, etc.). Similarly, $83.3 \%$ of patients with an anterior cruciate ligament pathology were male, $58.3 \%$ played football and the rest did a variety of sports (rugby, skiing, running, etc.). The patients' descriptive data are given in Table 2.

When analysing the different articular inflammatory, anabolism and catabolism markers in the two pathologies, together (Table 3) or separately, we did not notice statistically significant differences between the patients taking Carticure Plus ${ }^{\circledast}$ compared to the placebo regarding

Table 2. Description of the patients with a meniscus injury not associated with a ligament injury or a deficit of rough tissue and patients with an anterior cruciate ligament pathology.

\begin{tabular}{lcccc}
\hline & \multicolumn{2}{c}{ Meniscus } & \multicolumn{2}{c}{ Ligament } \\
& Mean & Std. dev. & Mean & Std. dev. \\
\hline Age & 36.99 & 4.9 & 37.65 & 6.30 \\
Weight & 79.92 & 10.12 & 76.38 & 6.70 \\
Height & 178 & 7.01 & 172.42 & 7.79 \\
BMI & 25.24 & 3.02 & 25.72 & 1.91 \\
\hline
\end{tabular}

Std. Dev.: Standard deviation; BMI: Body mass index.

Table 3. Inflammatory indicators of articular anabolism and catabolism.

\begin{tabular}{|c|c|c|c|}
\hline & & CP & CTRL \\
\hline $\begin{array}{l}\text { PCR } \\
\text { (mean) }\end{array}$ & $\begin{array}{l}\text { Baseline } \\
3 \text { months } \\
\text { differential }\end{array}$ & $\begin{array}{l}306.15 \\
655.17 \\
394.09\end{array}$ & $\begin{array}{l}398.05 \\
610.10 \\
270.86\end{array}$ \\
\hline $\begin{array}{l}\text { FGF } \\
\text { (mean) }\end{array}$ & $\begin{array}{l}\text { Baseline } \\
3 \text { months } \\
\text { differential }\end{array}$ & $\begin{array}{r}8.64 \\
8.56 \\
-0.08\end{array}$ & $\begin{array}{r}7.80 \\
3.12 \\
-4.67\end{array}$ \\
\hline $\begin{array}{l}\text { TGF } \\
\text { (mean) }\end{array}$ & $\begin{array}{l}\text { Baseline } \\
3 \text { months } \\
\text { differential }\end{array}$ & $\begin{array}{c}634.20 \\
685.47 \\
68.78\end{array}$ & $\begin{array}{c}642.73 \\
788.74 \\
49.43\end{array}$ \\
\hline $\begin{array}{l}\text { TNFa } \\
\text { (mean) }\end{array}$ & $\begin{array}{l}\text { Baseline } \\
3 \text { months } \\
\text { differential }\end{array}$ & $\begin{array}{c}22.57 \\
24.93 \\
2.36\end{array}$ & $\begin{array}{l}24.68 \\
33.34 \\
11.48\end{array}$ \\
\hline $\begin{array}{l}\text { IL1b } \\
\text { (mean) }\end{array}$ & $\begin{array}{l}\text { Baseline } \\
3 \text { months } \\
\text { differential }\end{array}$ & $\begin{array}{c}27.17 \\
29.53 \\
0.60\end{array}$ & $\begin{array}{c}28.29 \\
16.60 \\
-11.00\end{array}$ \\
\hline $\begin{array}{l}\text { IL6 } \\
\text { (mean) }\end{array}$ & $\begin{array}{l}\text { Baseline } \\
3 \text { months } \\
\text { differential }\end{array}$ & $\begin{array}{l}3.33 \\
3.35 \\
0.02\end{array}$ & $\begin{array}{r}4.62 \\
2.79 \\
-1.37\end{array}$ \\
\hline $\begin{array}{l}\text { HA } \\
\text { (mean) }\end{array}$ & $\begin{array}{l}\text { Baseline } \\
3 \text { months } \\
\text { differential }\end{array}$ & $\begin{array}{l}38.98 \\
35.96 \\
-3.03\end{array}$ & $\begin{array}{c}48.36 \\
50.03 \\
1.67\end{array}$ \\
\hline $\begin{array}{l}\text { Col2a } \\
\text { (mean) }\end{array}$ & $\begin{array}{l}\text { Baseline } \\
3 \text { months } \\
\text { differential }\end{array}$ & $\begin{array}{c}25.01 \\
24.54 \\
0.67\end{array}$ & $\begin{array}{l}24.79 \\
23.33 \\
-0.35\end{array}$ \\
\hline
\end{tabular}

CP: CarticurePlus; CTRL: control; PCR: Protein C reactive; FGF: fibroblast growth factor; TGF: transforming growth factor; TNFa: tumour necrosis factor a; IL1 b: Interleukin 1 \%; IL6: Interleukin 6; HA: hyaluronic acid; Col2a: collagen 2a. the difference in the value obtained at the baseline moment, after three months or in the difference between the basal moment and after three months.

Tables 4, 5 and 6 show the evolving results of the EVA scales and the WOMAC and KOOS questionnaires for the patients.

In meniscal pathologies there are no statistically significant differences regarding the decrease in pain measured by the EVA scale in the first month compared to the baseline $(p=0.24)$, where the average drop of pain between Carticure Plus ${ }^{\oplus}$ and the control group is 2.83 (CPmEVA) and 1.6 (CtrlmEVA) respectively, with results from the second month $(p=0.48$, CPmEVA=3.33, CtrlmEVA $=3$ ) and the third month ( $p=0.84, \mathrm{CPmEVA}=2.8$, CtrlmEVA=3). Similarly, in ligament pathologies, no statistically significant differences were obtained regarding the reduction of pain measured by the EVA scale when we compare the improvement in pain with the baseline moment after one month ( $p=0.48, C P m E V A=1.83, \mathrm{Ctr} / \mathrm{mEVA}=0.83$ ). After two months ( $p=0.54, C P m E V A=1.83$, CtrlmEVA=1.8) and after three months ( $p=1, C P m E V A=2.83$, CtrlmEVA=2.4).

When considering the whole set of patients, an improvement is obtained in the functional capacity of the WOMAC scale among patients taking Carticure Plus ${ }^{\oplus}$ compared to the placebo $(p=0.04$, CP average

Table 4. Pain evaluation on the EVA scale.

\begin{tabular}{lllllll}
\hline & \multicolumn{3}{c}{ Meniscus } & \multicolumn{3}{c}{ Ligament } \\
& Month & Mean & Std. dev. & Month & Mean & Std. dev. \\
\hline \multirow{2}{*}{ Carticure Plus } & 0 & 4.83 & 1.47 & 0 & 4.33 & 1.97 \\
& 1 & 2.00 & 1.10 & 1 & 2.50 & 0.84 \\
& 2 & 1.50 & 2.35 & 2 & 2.50 & 1.52 \\
& 3 & 1.60 & 2.07 & 3 & 1.50 & 1.98 \\
Control & 0 & 3.83 & 0.75 & 0 & 3.50 & 1.64 \\
& 1 & 2.17 & 0.98 & 1 & 2.67 & 1.37 \\
& 2 & 0.83 & 0.41 & 2 & 2.20 & 0.84 \\
& 3 & 0.83 & 0.45 & 3 & 1.60 & 1.14 \\
\hline
\end{tabular}

Std. Dev.: Standard deviation

Table 5. WOMAC Questionnaire.

\begin{tabular}{|c|c|c|c|c|c|c|c|}
\hline & \multirow[b]{2}{*}{ Month } & \multicolumn{2}{|c|}{ Pain } & \multicolumn{2}{|c|}{ Rigidity } & \multicolumn{2}{|c|}{$\begin{array}{l}\text { Functional } \\
\text { capacity }\end{array}$} \\
\hline & & Mean & $\begin{array}{l}\text { Std. } \\
\text { dev. }\end{array}$ & Mean & $\begin{array}{l}\text { Std. } \\
\text { dev. }\end{array}$ & Mean & $\begin{array}{l}\text { Std. } \\
\text { dev. }\end{array}$ \\
\hline \multicolumn{8}{|l|}{ Meniscus } \\
\hline \multirow[t]{2}{*}{ Carticure Plus } & 50 & 6.33 & 3.83 & 2.50 & 1.64 & 19.83 & 12.70 \\
\hline & 3 & 1.00 & 1.73 & 1.80 & 3.49 & 4.40 & 7.80 \\
\hline \multirow[t]{2}{*}{ Control } & 0 & 2.83 & 1.72 & 1.33 & 1.03 & 8.83 & 6.49 \\
\hline & 3 & 1.00 & 0.71 & 0.40 & 0.55 & 2.40 & 2.70 \\
\hline \multicolumn{8}{|l|}{ Ligament } \\
\hline \multirow[t]{2}{*}{ Carticure Plus } & 0 & 6.17 & 6.21 & 3.17 & 2.40 & 24.83 & 21.19 \\
\hline & 3 & 1.67 & 3.61 & 1.67 & 1.51 & 6.33 & 10.37 \\
\hline \multirow[t]{2}{*}{ Control } & 0 & 4.33 & 4.63 & 2.50 & 2.35 & 17.83 & 16.62 \\
\hline & 3 & 2.40 & 2.30 & 1.80 & 1.79 & 10.20 & 10.87 \\
\hline
\end{tabular}

Std. Dev.: Standard deviation. 
Table 6. KoOS Questionnaire.

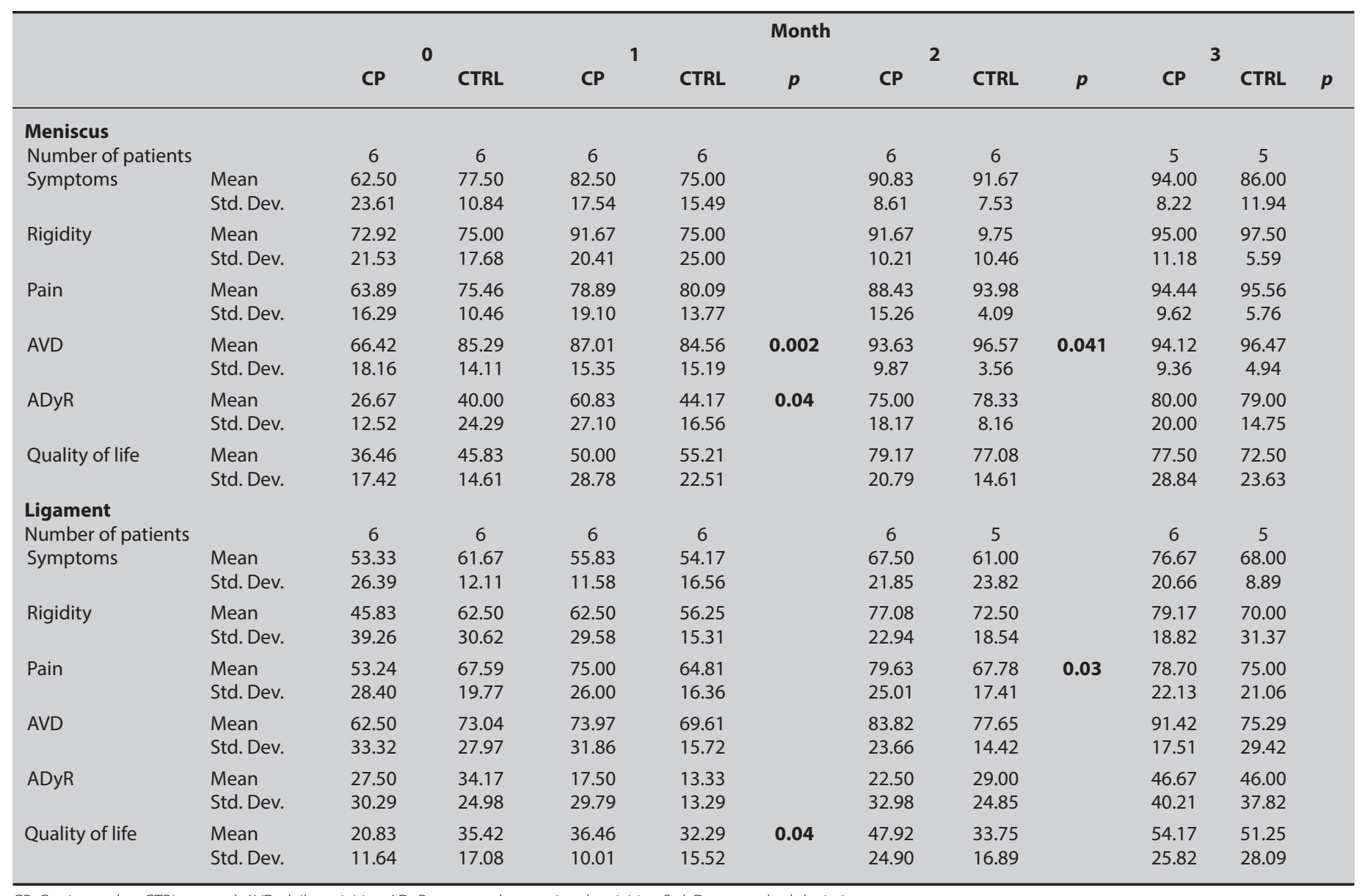

CP: Carticure plus; CTRL: control; AVD: daily activities; ADyR: sport and recreational activities; Std. Dev: standard deviation.

increment of 16.97 points, $76 \%$ compared to Ctrl of 7.03 points, 53\%) between the final and baseline visit. The pain dimension for the same scale is close to a statistically significant difference $(p=0.055, \mathrm{CP}$ average increment of 4.92 points, $79 \%$ compared to the Ctrl of 1.86, 53\%), with no differences seen in the rigidity subscale.

Statistically significant differences can be observed in the improvement of the Carticure Plus ${ }^{\circledR}$ group compared to the placebo for the subscale of daily life activity (KOOS) between the basal visit and the first visit (one month from the initial visit) in the meniscal pathology $(p=0.002$, CP average increment of 20.59 points, 31\% compared to Ctrl of -0.74 points, $-1 \%)$. This difference is maintained between the baseline visit and the second visit (two months) in the meniscal pathology ( $p=0.041, C P$ average increment of 27.21 points, $41 \%$ compared to $C$ trl of 11.27 points, 13.2\%). Statistically significant differences were also observed in favour of Carticure Plus ${ }^{\circledast}$ on the subscale of sports and recreational activities (KOOS) in the meniscal pathology between the baseline visit and the visit the following month ( $p=0.04, C P$ average increment of 34.17 points, $128 \%$ compared to Ctrl of 4.17 points, $10.4 \%$ ). We also detect statistically significant differences in the Carticure Plus ${ }^{\oplus}$ group compared to the placebo for the subscale of daily life activity (KOOS) between the basa visit and the visit carried out the following month ( $p=0.04$, CP average increment of 15.63 points, $75 \%$ compared to Ctrl of -3.13 points, $-8.8 \%$ ) in the ligament pathology. In the latter pathology, we also observed improvements in pain among the Carticure Plus ${ }^{\oplus}$ group compared to the placebo ( $p=0.03, C P$ average increment of 26.39 points, $49.6 \%$ compared to $\mathrm{Ctrl}$ of 0.19 points, $0.3 \%$ ) between the second and the baseline month. If we consider all the patients, irrespective of the type of pathology, we see an improvement in pain (KOOS subscale) between the baseline and first visit in favour of Carticure Plus ${ }^{\circledast}$ compared to the placebo ( $p=0.007$, CP average increase of 18.38 points, $31.4 \%$ compared to $C$ trl of 0.93 points, $1.3 \%$ ) and an improvement in daily life activities between the baseline visit and the visit after one month ( $p=0.007, \mathrm{CP}$ average increase of 16.03 points, $24.9 \%$ compared to Ctrl of -2.08 points, $-2.6 \%$ ), after two months ( $p=0.027, C P$ average increase of 24.26 points, $37.6 \%$ compared to Ctrl of 7.94 points, $10 \%$ ) and after three months ( $p=0.024, \mathrm{CP}$ average increase of 28.31 points, $43.9 \%$ compared to $\mathrm{Ctr}$ of 21.42 points, $27.1 \%$ ). In no case are statistically significant differences seen $(p<0.05)$ between the two groups at the baseline visit. 


\section{Discussion}

In the clinical data, despite the small sample size, statistically significant differences in clinical improvement are seen in favour of Carticure Plus ${ }^{\oplus}$ compared to the placebo. During the first month, the KOOS scale showed an improvement in pain, activities in daily life, sports and recreational activities and quality of life (Figures 1 and 2).

This makes it possible to detect a faster improvement, that equals out over the three months in the case of the ligament injury (Figures 3 and 4 ) but in the case of the meniscal injury a clinical improvement is

Figure 1. KOOS scale, baseline moment, after one month and after 3 months, in patients with meniscus injury not associated with ligament injury or deficit of rough tissue. (CP: Carticure Plus ${ }^{\circledR}$ ).

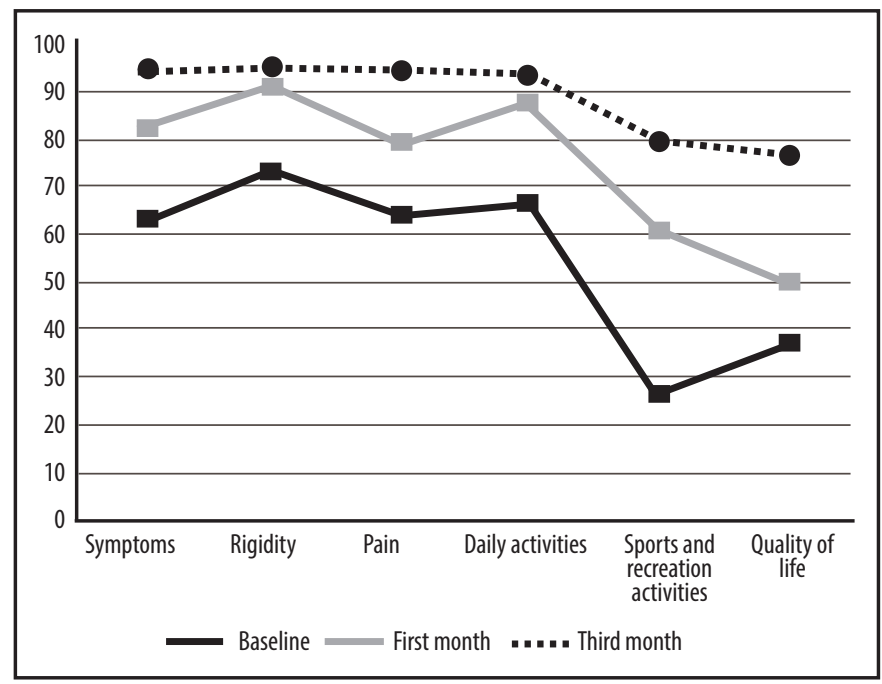

Figure 2. KOOS scale, baseline moment, after one month and after 3 months, in patients with meniscus injury not associated with ligament injury or deficit of rough tissue. (CTRL: Control).

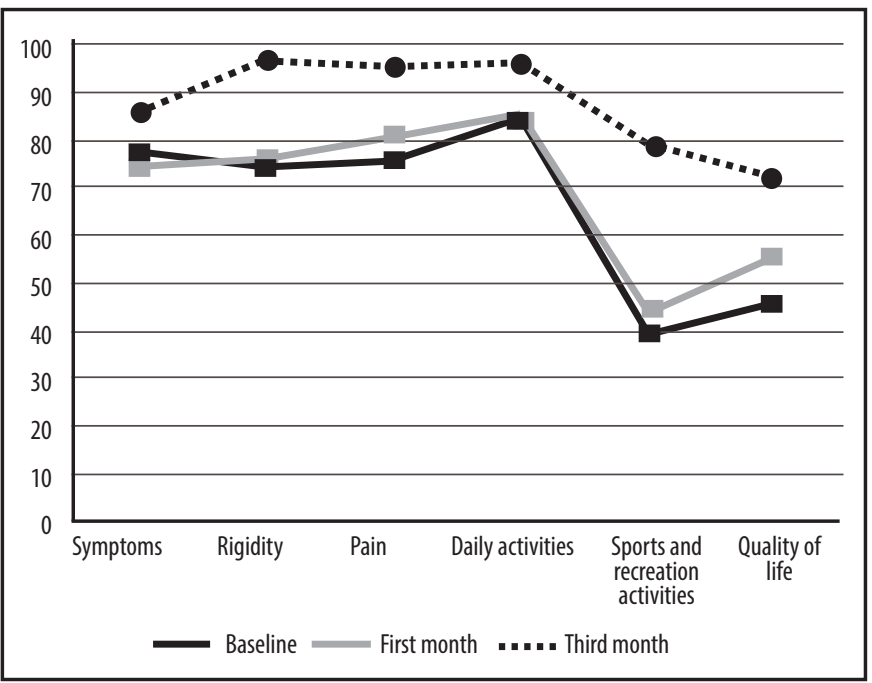

maintained in the Carticure Plus ${ }^{\oplus}$ group. Despite the small number of patients, statistically significant differences were observed in the daily activities, sport and recreational activities in meniscal injuries between the baseline visit and the first month, and in quality of life in ligament pathologies between the baseline visit and the first month. It should be highlighted that statistically significant differences were found in very few cases (12 patients in each pathological group), which favours the clinical evaluation of improvement in the first month of Carticure Plus ${ }^{\circledast}$ In the set of 24 patients, the improvement in pain after one month and the improvement of daily life after one, two and three months leads us

Figure 3. KOOS scale, baseline moment, after one month and after 3 months, in patients with anterior cruciate ligament pathology. (CP: Carticure Plus ${ }^{\oplus}$ ).

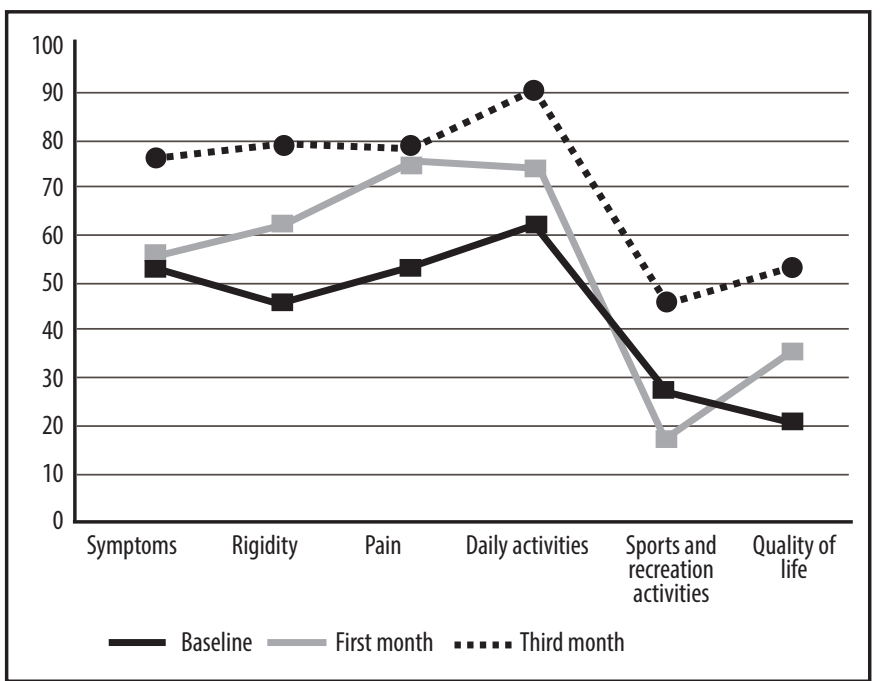

Figure 4. KOOS scale, baseline moment, after one month and after 3 months, in patients with anterior cruciate ligament pathology. (CTRL: Control).

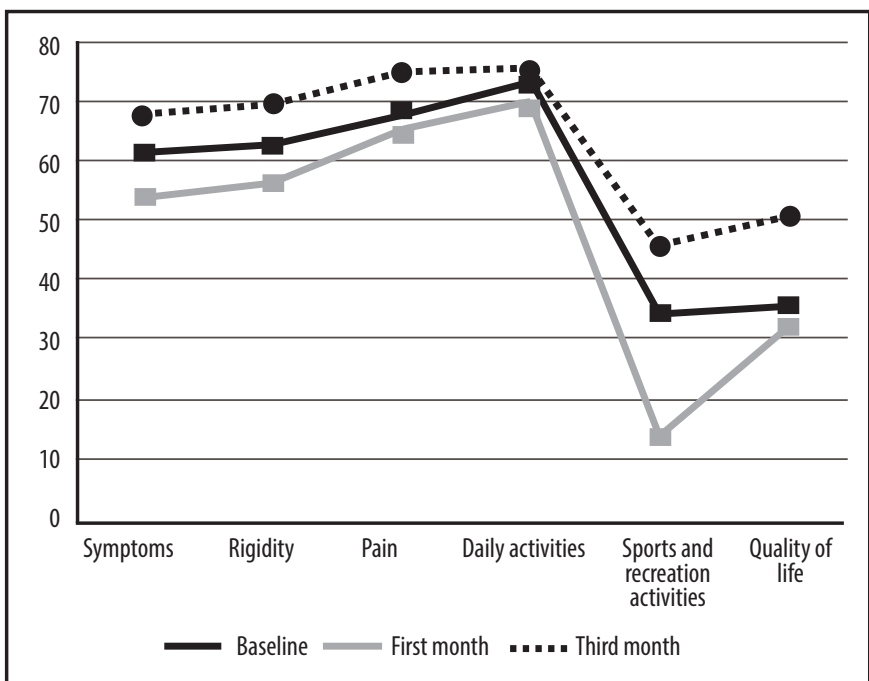


to believe that the faster improvement associated with Carticure Plus ${ }^{\oplus}$ produces a sustained recovery that lasts for all three months compared to the absence of food supplement, that might be explained by the characteristics of the product. Detecting differences, the three-month improvement on the WOMAC scale regarding functional capacity and only just missing out on this improvement in pain on the same scale in this reduced set of 24 patients demonstrate a measurement of the high impact of Carticure Plus ${ }^{\circledast}$ in improving pathologies.

The sample size has not made it possible to discriminate statistically significant differences for the markers analysed between the patients treated with Carticure Plus ${ }^{\circledR}$ and placebo. It remains to be determined which blood biomarkers might offer a better approximation to the diagnosis and prognosis of developing early onset OA after this type of surgery. It is undeniable that we need to design new studies on this line. In the same way, it could be particularly useful to associate concentrations of these biomarkers with other new magnetic resonance diagnostic tests.

Therefore, we can conclude that incorporating Carticure Plus ${ }^{\circledast}$ for three months, after the surgical intervention on the meniscal or ligament pathology will improve the clinical response quickly in the first month and this will give better values in terms of daily activities in all patients after three months.

\section{Conflict of interests}

The authors do not declare any conflict of interests.

\section{Bibliography}

1. Gianotti SM, Marshall SW, Hume PA, Bunt L. Incidence of anterior cruciate ligament injury and other knee ligament injuries: a national population based study. J Sci Med Sport. 2009;12:622-7.

2. Wang X, Wang Y, Bennell KL, Wrigley TV, Cicuttini FM, Fortin K, et al. Cartilage morphology at 2-3 years following anterior cruciate ligament reconstruction with or without concomitant meniscal pathology. Knee Surg Sports Traumatol Arthrosc. 2015 Oct 27.

3. Ajuied A, Wong F, Smith C, Norris M, Earnshaw P, Back D, et al. Anterior cruciate ligament injury and radiologic progression of knee osteoarthritis: a systematic review and meta-analysis. Am J Sports Med. 2014;42:2242-52.

4. Luc B, Gribble PA, Pietrosimone BG. Osteoarthritis prevalence following anterior cruciate ligament reconstruction: a systematic review and numbers-needed-to-treat analysis. J Ath/ Train. 2014;49:806-19.

5. Thorlund JB, Holsgaard-Larsen A, Creaby MW, Jørgensen GM, Nissen N, Englund M, et al. Changes in knee joint load indices from before to 12 months after arthroscopic partial meniscectomy: a prospective cohort study. Osteoarthritis Cartilage. 2016;24:1153-9.

6. Khan HI, Aitken D, Ding C, Blizzard L, Pelletier J-P, Martel-Pelletier J, et al. Natural history and clinical significance of meniscal tears over 8 years in a midlife cohort. BMC Musculoskelet Disord. 2016;17:4

7. Abram SGF, Price AJ, Judge A, Beard DJ. Anterior cruciate ligament (ACL) reconstruction and meniscal repair rates have both increased in the past 20 years in England: Hospital statistics from 1997 to 2017. Brit J Sport Med. 2020;54:286-91.

8. Golightly YM, Marshall SW, Kraus VB, Renner JB, Villaveces A, Casteel C, et al. Biomarkers of incident radiographic knee osteoarthritis: do they vary by chronic knee symptoms? Arthritis Rheum. 2011;63:2276-83.

9. Guevara U, Covarrubias A, Delille R, Hernández A, Carrillo R, Moyao D. Parámetros de práctica para el manejo del dolor agudo perioperatorio. Cir Ciruj. 2005;73:223-32.

10. Escobar A, Vrotsou K, Bilbao A, Quintana JM, García Pérez L, Herrera-Espiñeira C. Validación de una escala reducida de capacidad funcional del cuestionario WOMAC. Gac Sanit. 2011;25:513-8.

11. Álvarez A, García Y, López G, López M, Áreas Y, Ruiz de Villa A. Artrosis de la rodilla y escalas para su evaluación. Archivo Médico de Camagüey [Internet]. 2012;16:1777-90. Recuperado de: https://www.red alyc.org/articulo.oa?id=211125504014 [Consultada 17/05/2019]. 